\title{
Gendered Decision-Making About Mathematics Courses: Contributions of Self-Perceptions, Domain-Perceptions, and Sociocultural Factors
}

\author{
Jane Kirkham $^{1} \&$ Elaine Chapman ${ }^{1}$ \\ ${ }^{1}$ Graduate School of Education, University of Western Australia, Perth, Australia \\ Correspondence: Jane Kirkham, Graduate School of Education, University of Western Australia, Perth, Australia, \\ WA, 6009, Australia. Tel: 61-8-6488-2388. E-mail: jane.kirkham@research.uwa.edu.au
}

Received: March 11, 2020 Accepted: April 13, 2020 Online Published: April 23, 2020

doi:10.5539/jedp.v10n1p43 URL: http://doi.org/10.5539/jedp.v10n1p43

\begin{abstract}
Girls continue to be underrepresented in Year 11 and 12 intermediate and advanced mathematics courses in Australia, which has implications for their future educational opportunities and career aspirations. The present study compared the choices of 84 Year 10 girls and boys from one school for their Year 11 mathematics course, with their teachers' recommendations for the same. Findings indicated that while most participants made course selections aligned with their teachers' recommendations, girls tended to under-aspire and boys tended to over-aspire in their choice decisions, based on their teachers' recommended course choices. In addition, utilising the Expectancy-value theoretical (EVT) framework, we surveyed participants to measure their self-perceptions (self-concept), and values about mathematics (intrinsic value, utility value, and attainment value). We also measured participants' views on the domain of mathematics (sense of belonging, growth mindset, the status of mathematics, gender bias). Multivariate analysis of variance indicated that girls showed lowered self-concept, sense of belonging, and growth mindset than boys, also viewing mathematics as less of a high-status subject than boys. In addition, the survey obtained participants' opinions on sociocultural influences on their mathematics course selections, with no significant gender differences noted.
\end{abstract}

Keywords: gender, mathematics, sociocultural environment, value

\section{Introduction}

In Australia, girls and boys with similar proficiency in mathematics and sciences have been found to make different choices about undertaking Science, Technology, Engineering and Mathematics (STEM) subjects at the upper secondary level, which may affect their higher education and career opportunities (Broadley, 2015; Jeffries, Curtis, \& Connor, 2019; Timms, Moyle, Weldon, \& Mitchell, 2018; Watt et al., 2012). Fewer girls than boys choose to undertake advanced mathematics courses in Year 11 and 12 in comparison to other mathematics courses (Barrington \& Evans, 2014; Li \& Koch, 2017; Wilson \& Mack, 2014). Given that the choice to study the more demanding maths courses has the potential to serve as critical filter in accessing future educational options and influencing career aspirations noted in both local and international contexts (Watt et al., 2017; Watt \& Goos, 2017), the main aim of this study is to investigate salient influential factors associated with mathematics course selections for girls and boys.

Lack of engagement in advanced mathematics courses has been reported to result from a complex reciprocal interaction between personal and social factors, which may affect girls and boys differently (see Kirkham, Chapman, \& Wildy, 2019). Potential influences on students' subject choice decisions have been described as 'inside-out' and 'outside-in' factors (Roeser, 2006; Spearman \& Watt, 2013). The 'inside-out' view focusses on psychological processes, such as personal beliefs and values, as key factors in subject choice decisions. The 'outside-in' perspective emphasises social forces as instrumental in providing opportunities and creating barriers for girls' educational choices, for example, by positioning them as less competent, or by reducing the value that girls assign to mathematics as a discipline. This dual perspective enables the generation of a range of factor sets for investigation, specifically, individual (self- and domain-specific beliefs, personal values), home (perspectives of the expectations of parents and other family members), and school (judgements on the influence of teachers and peers). Recent research in the mathematics domain has explored each of these factors in investigating educational 
engagement (Martin, Anderson, Bobis, Way, \& Vellar, 2012; Martin \& Lazdendic, 2018; Martin, Way, Bobis, \& Anderson, 2015; Wang \& Eccles, 2012).

\subsection{Individual Factors}

\subsubsection{Mathematics Self-Perceptions}

An individual's motivation to study a specific mathematics course may be influenced by personal perceptions of mathematical ability and expectations of success in the mathematics course considered. Self-perceptions, therefore, are both domain-specific (mathematics self-concept) and task specific (i.e., relating to beliefs about potential for success in specific mathematics tasks, referred to as mathematics self-efficacy). Arguably, mathematics self-concept is more useful in predicting choice behaviours in that it is based on personal evaluations of domain-specific competence (Marsh, 2007; Marsh et al., 2018). The construct of academic self-concept intersects with the expectancy element of Expectancy Value Theory (Eccles et al., 1983; Eccles, 1987), a theoretical framework that has informed much of the work on beliefs and attributions towards the study of mathematics. According to EVT, achievement in a domain is predicated upon an expectation of success in that domain, in combination with a sense of valuing the domain (Wigfield \& Eccles, 2000; Eccles \& Wigfield, 2002). Modern EVT theorists operationalise an expectancy of success through self-concept responses (Eccles, 2009; Guo, Parker, Marsh, \& Morin, 2015; Trautwein et al., 2012).

\subsubsection{Perceptions of the Value of Mathematics}

A key predictor of mathematics participation and choice is the subjective value assigned to the subject area by the individual (Wang \& Kenny, 2014). The notion of subjective task value is the second of the two components of EVT. Value is conceptualised as encompassing four key facets: intrinsic value, utility value, attainment value, and cost value (Eccles, O'Neill, \& Wigfield, 2005; Wigfield \& Eccles, 2000). Research on gender differences in task values has produced some inconsistent findings, partly because a number of studies have collapsed task value facets into one general value scale (see Gaspard et al., 2015). More recent research, however, has investigated value facets separately.

Intrinsic value relates to the interest level or enjoyment factor experienced by an individual when engaging in a task. Girls have been reported consistently to show lower levels of interest in mathematics than boys (Frenzel, Goetz, Pekrun, \& Watt, 2010; Gaspard et al., 2015; Lazarides \& Ittel, 2013; Watt, 2016). Being interested in a subject predicts on-going engagement and further subject choice (Watt et al., 2017). Previous studies have drawn a link between intrinsic value and gendered educational and career choices (Guo et al, 2015; Lazarides, Rubach, \& Ittel, 2017). Specifically, Watt et al. (2012) reported that differences in intrinsic values predicted educational aspirations in Australian adolescents.

Attainment value and utility value focus on the importance aspect of a task. Attainment value is an evaluation of a task in terms of how closely it corresponds to a sense of identity, that is, the importance of being seen to do well in a subject. Utility value is associated with the perceived usefulness of the task in achieving personal goals. Utility and attainment values have been found to influence academic engagement in secondary school students (González, Paoloni, Donolo, \& Rinaudo, 2015; Watt et al., 2012). Fewer differences in mathematics attainment and utility value between girls and boys have been reported than is the case with intrinsic value (Watt, 2004; Watt et al., 2012). However, recent research has suggested that a more nuanced interpretation of utility value, in particular, may throw more light on gender differences in value. Fadda, Scalas, Morin, Marsh, and Gaspard (2019) divided utility value into three facets: utility for school (with respect to school-aged students); utility for life; and social utility. Their results indicated that, while girls found mathematics to be more useful in school than boys, the opposite was the case in relation to general utility for future life.

Cost value encapsulates the negative consequences of engagement in a task (Watt, 2016). Originally conceptualised as a mediator of positive aspects of value (Eccles et al., 1983), more recently cost value has been considered to be a type of value (Wigfield \& Eccles, 2000), or a separate component to expectancy and value (Barron \& Hullman, 2014). Historically, cost value has been less extensively researched because of a lack of consensus in definition and measurement (Chen \& Liu, 2009). A major limitation in scales to measure cost value is that cost items, by necessity, focus on particular issues relevant to the population tested and the nature of the activity appraised, thereby lacking generalisation (for a discussion see Flake, Barron, Hulleman, McCoach, \& Welsh, 2015). This would suggest that, while cost value appears to be important in balancing risks with benefits of choice decisions, more research is required in order to operationalise cost value theoretically and empirically. As a result, this current study focusses only on other elements of the EVT framework. 


\subsubsection{Perceptions of Mathematics as a Subject Area}

Mathematics engagement has been reported to be influenced by domain-specific beliefs about the status of the discipline, a perception of how mathematics knowledge is acquired, and opinions on who best acquires it. Recent research has suggested that the discipline of mathematics is perceived by some to be a more prestigious discipline than other domains of learning due the nature and the demand of the knowledge base (Bleazby, 2015; Francis, Mills, \& Lupton, 2017). For example, mathematics has a long-established subject matter that emphasises certainty, reliability and absolute truths, in addition, it contains abstract and theoretical concepts that are considered to be intellectually challenging. A central tenet in mathematics is that knowledge is constructed through reason and justification in a search for truth. According to Francis, Archer, Moote, de Witt and Yeomans (2017), these are aptitudes historically associated with masculinity. In addition, those with high mathematics ability are thought to possess 'raw aptitude' or 'natural brilliance' acquired innately, characteristics that some researchers have posed to be ascribed more often to men than to women (Leslie, Cimpian, Meyer, \& Freeland, 2015). Two prevailing gender stereotypes are the result: that mathematics is a masculine field; and that boys are better at mathematics than girls. Gendered mathematics stereotypes have been reported in a range of countries globally (Ernest, Reinholz, \& Shah, 2019). The presence of gender stereotypes serves to limit the potential for female identification with mathematics as a subject, thereby reducing their sense of belonging in the field. A sense of belonging is a psychological state associated with the feeling of membership in, or acceptance by, a group. Belongingness brings positive benefits in terms of personal goals and future plans (Ryan \& Deci, 2000). Conversely, a lack of sense of belonging has been attributed by some to reduce interest in an endeavour, and this may be particularly true for females in the male-dominated fields, such as mathematics (Good, Rattan, \& Dweck, 2012; Pietri et al., 2019). Unfortunately, the view that boys are more competent in mathematics than girls remains an on-going concern within Australian society (Leder, Forgasz, \& Jackson, 2014), and potentially an influential factor in the underrepresentation of girls in STEM (Hobbs et al., 2017).

The notion that mathematics knowledge and skills are the result of an innate and fixed quality has received attention through the work by Dweck and colleagues on the predictive effect of personal theory of intelligence, or "mindset" on mathematics self-concept and values. In other words, the educational goals that students set for themselves have been linked to their beliefs about the nature of intelligence and how it is formed (Blackwell, Trzesniewski, \& Dweck, 2007; Dweck, 2006; Dweck \& Leggett, 1988). Belief orientations have been referred to as "fixed" (i.e., entity) versus "growth" (i.e., incremental) mindsets. Specifically, those with an entity theory of intelligence believe that their ability is static and unchangeable, that they have a certain amount of competence in a subject area and that this is irrespective of effort. By implication, the goal of learning for individuals with a fixed mindset would be to demonstrate their ability through a performance standard. Conversely, incremental theorists believe that ability is malleable and can be cultivated with effort. A belief that ability is amenable to growth is more likely to result in a focus on advancing skills and a greater resilience in the face of challenges and setbacks (Dweck, 2006).

Differences in mathematics-specific mindsets may influence an individual's desire to pursue further studies. For example, fixed mindsets are more likely to undermine interest in a subject, while growth mindsets are more likely to promote feelings of competence and motivation to learn more (Good et al., 2012). Girls have been described as more likely to hold fixed mindsets in mathematics than boys (Degol, Wang, Zhang, \& Allerton, 2018; Dweck, 2013; Hwang, Reyes, \& Eccles, 2019; Seo, Shen, \& Alfaro, 2019), partly attributed to the possibility that in an environment in which fixed ability views predominate, negative views about the self can be thought of as unchangeable (Good, 2012; Pietri et al., 2019). Given this, it remains likely that the relationship between gender, mindset, task value, and aspirations is complex (Degol et al., 2018) and that further research to explore the mechanisms that underlie gender differences in mindsets and motivation is warranted.

\subsection{Home and School Factors}

\subsubsection{Home}

The context of the home and family provides an important environment for the development of motivation in relation to educational choices and career aspirations (Gemici, Bednarz, Karmel, \& Lim, 2014). Parents provide information and support to their school age children on academic choices and they communicate beliefs about their children's ability levels, as well as beliefs about the relative importance of different academic domains (Degol, Wang, Ye, \& Zhang, 2017; Korpershoek, Guntern, \& van der Werf, 2014). Gender stereotypes about mathematics can be perpetuated in the home environment in families with traditional expectations of gender roles (Bandura \& Bussey, 2004; Gunderson, Ramirez, Levine, \& Beilock, 2012). Parents also directly or indirectly influence their children's future career aspirations through the opportunities and support they provide (Lazarides et al., 2017). In 
addition, the sphere of influence on academic course choices and career aspirations has been extended to older siblings within the family. Older siblings are thought to exert a form of peer influence by providing advice and support and acting as role-models, especially if they have recent personal experience in studying the mathematics course options in question. Their impact, however, appears to be less strong than that of parents (Korpershoek et al., 2014).

\subsubsection{School}

Self-perceptions about competence and value are formed within an educational context and serve to mediate choices, both directly and indirectly (Nagy, Trautwein, Köller, Baumert, \& Garrett, 2006). Students' experiences in the classroom play an important role in influencing personal evaluations of a domain (Gunderson et al., 2012). Specifically, the quality of teaching is an important factor in student achievement and confidence (Hattie, 2009; Mullis, Martin, Foy, \& Arora, 2012; Jensen, Sonnemann, Roberts-Hull, \& Hunter, 2016; UNESCO, 2017). A perception of teacher expectations also impacts students' views of themselves as learners. Concerningly, several researchers have suggested that some teachers, like parents, may also hold gender stereotyped beliefs about their students' mathematics abilities (Gunderson et al., 2012; Legewie \& DiPrete, 2012). Others have suggested that teachers develop an unconscious bias against girls in mathematics (Blickenstaff, 2005), leading to them spend more time assisting boys than girls in learning activities (Quaglia et al., 2013; Shumow \& Schmidt, 2013; Spilt, Koomen, \& Jak, 2012). Notwithstanding the importance of teachers and the classroom climate, the opinions of peers and friends in the adolescent stage of development may also influence an individual's interests and choices (Tajfel \& Turner, 1986). For example, peer support has been shown to increase the likelihood of girls in enrolling in advanced mathematics courses (Breakwell, Vignoles, \& Robertson, 2003; Riegle-Crumb, Farkas, \& Muller, 2006; Robnett \& Leaper, 2012). The sociocultural aspect of the learning environment of the school is likely to be an important source of influence in students' mathematics course choices for Year 11.

\subsection{The Present Study}

In the current study, we sought to discover if gendered mathematics enrolment patterns noted nationally were present in the course selections from all Year 10 students at one school. Then, using an original survey of 45 items, we investigated the expectancy and value beliefs about studying mathematics based on the definitions of expectancy and value in EVT. We also measured students' beliefs about mathematics as a domain, as well as their opinions on sociocultural sources of influence on their mathematics course choices. The research questions addressed in this study were: Research Question 1: What Year 11 mathematics course choices did Year 10 boys and girls of different achievement levels make? Research Question 2: Controlling for achievement level, do boys and girls differ in their mathematics self-perceptions, perceptions of the value of mathematics, and in their perceptions of mathematics as a subject area? Research Question 3: What sociocultural factors influenced girls' and boys' of different achievement levels mathematics course choices?

\section{Method}

\subsection{Participants}

The sample comprised the full cohort of Year 10 students enrolled at one coeducational school in Western Australia (WA) that offers the Western Australian Certificate of Education (WACE) mathematics courses: Mathematics Essential General; Mathematics Applications; Mathematics Methods; and Mathematics Specialist. In WA, students in their final years of secondary schooling (Years 11 and 12) choose from a selection of courses in order to achieve their WACE certificate. Many undertake the more demanding Australian Tertiary Admission Rank (ATAR) courses often used as a common pathway to university entrance. These courses result in an ATAR score at the end of Year 12 that represents a students' rank in relation to others in their age group across the state. Of the four mathematics courses available at the sample school, Mathematics Essential General is the only non-ATAR mathematics course. This focusses on mathematical skills required in real world contexts. Of the three ATAR mathematics courses, Mathematics Applications is the non-calculus course designed for students who wish to extend their mathematics knowledge beyond the Year 10 curriculum. Mathematics Methods is an intermediate level course that includes calculus and statistical analysis necessary for following pathways that require mathematics at tertiary level. Mathematics Specialist is the most advanced course and may only be undertaken in combination with Mathematics Methods. Mathematics Specialist is recommended for those intending to study tertiary courses in mathematics, engineering, or physics (School Curriculum and Standards Authority, 2014).

The study included 84 participants, of whom $46(54.8 \%)$ were girls and $38(45.2 \%)$ were boys. Participants were aged $15(n=48,57.1 \%)$ or $16(n=36,42.9 \%)$. One participant $(1.2 \%)$ identified as being of Aboriginal or Torres Strait Islander origin. Five participants (5.6\%) spoke a language other than English at home. Of the participants, 47 
$(56.0 \%)$ indicated that they had an older sibling in Year 11 or 12 in 2018, or an older sibling who had completed secondary school within the previous five years, $37(44.0 \%)$ did not have an older sibling in Year 11 or Year 12 or an older sibling who had finished school recently.

Prior to the survey, school staff provided data on teacher recommendation for Year 11 mathematics course(s) for each participant. This reflected the highest mathematics course that school staff considered that each participant could complete successfully in Year 11. Data indicated that each participant was recommended to undertake one of the four available options at this school; Mathematics Essential General; Mathematics Applications; Mathematics Methods; and the combination of Mathematics Methods and Mathematics Specialist. This information served as a proxy for current level of achievement, as recommendations were based on individual student grades. Participants receiving an A grade were advised to take the Mathematics Methods and Mathematics Specialist combination. Participants receiving a B grade were recommended to study Mathematics Methods alone, while participants receiving a $\mathrm{C}$ grade or below were advised to take Mathematics Applications. Several participants receiving a $\mathrm{C}$ grade were advised to take Mathematics Essential General, as were participants who were following a modified Year 10 mathematics curriculum. In analysing data according to achievement level, participants were then assigned to one of two achievement groups, Standard (Mathematics Essential General; Mathematics Applications) or Advanced (Mathematics Methods, Mathematics Methods and Mathematics Specialist). One item in the survey asked participants to indicate their Year 11 mathematics course selection. The five options were: No mathematics; Mathematics Essential General; Mathematics Applications; Mathematics Methods; Mathematics Methods and Mathematics Specialist. Participants' stated course choice was compared to the teacher recommendations according to achievement group, resulting in participants being described as aligned (participant course choice and teacher recommended course matching), over-aspiring (participant course choice higher than teacher recommended course), or under-aspiring (participant course choice lower than teacher recommended course).

\subsection{Instrument}

The survey was organised into two sections: (i) perceptions about studying mathematics; (ii) sociocultural sources of influence on mathematics course choices. Most of the items were adapted from existing instruments measuring self- and domain-specific psychological constructs drawn from the literature (for example, EVT), as specifically stated in the sub-sections below. Other items were inspired by verbatim comments that emerged from a locally based qualitative investigation of influential factors on Year 10 students' mathematics course selections (Kirkham et al., 2019).

Survey items were presented in a bipolar slider format anchored with statements at each of the endpoints to encapsulate opposing qualities of the same concept. This allowed participants to respond by indicating the relative strength of their attitude towards each concept. Participants responded by selecting a point on a continuum between the endpoints by moving a marker along an absolute metric 11-point scale, presented visually as a slider. The benefit of the use of a bipolar scale is that is captures extremes of opinions while allowing for a neutral response. A slider format was adopted for this population of adolescent participants because of its potential to increase engagement through a more interactive approach to responding (Roster, Lucianetti, \& Albaum, 2015). The starting point for the marker was the middle of the scale, as noted by Bosch, Revilla, DeCastellarnau, and Weber (2019) as useful in reducing response style bias and extreme responding. To reinforce the meaning and polarity of the opposing statements, numerical labels appeared at each point along the 11-point continuum as the participant moved the marker along the slider. The use of an 11-point scale increased granularity and reduced potential grade inflation.

\subsubsection{Perceptions About Studying Mathematics}

This section included 5 items to assess self-perceptions in relation to mathematics, 18 items to measure personal values, and 8 items related to perceptions of mathematics as a subject area.

a. Self-perception items. 5 items were designed to assess beliefs associated with mathematics self-concept, ie. I expect to achieve poorly in maths assignments (1), I expect to achieve highly in maths assignments (11), as adapted from the success expectancy items from Wigfield and Eccles (2000) and Watt (2004).

b. Personal value items. 5 items assessed perceptions of the intrinsic value of mathematics, ie. I hate studying maths (1), I love studying maths (11). A further 5 items were designed to measure the attainment value of studying mathematics, ie. Achieving highly in maths does not matter to me (1), Achieving highly in maths is very important to me (11). 4 items addressed the general utility of mathematics courses for an individual's future, ie. Having a high level of maths skills is not necessary in my potential future job/career (1), Achieving a high level of maths skills is very important in my potential future job/career (11). These items were referred 
to as utility value-general. This section included items adapted from task value items detailed in Watt (2004). An additional 4 items asked about the utility value of mathematics courses specific to school-based decisions within the local context, for example, the importance of gaining a high score for university entrance or of university perquisites. These items were drawn from the qualitative data in Kirkham et al. (2019), for example, My ATAR score is not important to me at all (1), Achieving a very high ATAR score is extremely important to me (11). These items were referred to as utility value-school.

c. Perceptions of mathematics as a subject area items. 5 items measured participants' sense of belonging in the mathematics field adapted from the Math Sense of Belonging Scale (Good, Rattan \& Dweck, 2012), ie. I feel like a stranger in the maths world (1), I feel like I really belong in the maths world (11). Three single items were included about the type of people who succeed in mathematics, how mathematics competencies are formed, and the social status of those who achieve highly in mathematics. Of these single items, one item created for this survey was designed to measure gender bias, (ie. I think that boys have far more ability in maths than girls (1), I think that girls have far more ability in maths than boys (11)). A further item measured entity versus incremental theories of intelligence in that mathematics ability was innate ie. I believe that some people are born with natural maths ability (1), I believe that maths ability can be learned (11)). This was adapted from the three-item scale on the implicit theory of intelligence developed by Dweck, Chiu \& Hong (1995). The final single item was created to assess perspectives on the social standing of mathematics as a domain, ie. It's much better to be excellent at maths than it is to be excellent at other subjects (1), It doesn't matter at all which subjects you excel at (11).

\subsubsection{Sources of Influence on Mathematics Course Choices}

The survey included nine items asking participants who influenced them in their Year 11 mathematics course decision-making. Each item was stated as, "How important were [insert group name] in influencing your decision about ATAR maths course selections?" The groups were: parents or guardians; brothers or sisters; other family members; friends; older students; teachers; someone else you don't know personally; someone else who is famous or a role-model; media. Most of these sources of influence on students' mathematics course choices were identified in recent research with a similar population (see Kirkham et al., 2019). Participants responded using an 11-point bipolar numeric slider anchored with the statements "not important at all" (1) to "extremely important" (11). The item referring to brothers and sisters was only analysed for those participants $(n=47)$ who responded in the affirmative to the initial item asking if they had an older brother or sister who was in Year 11 or 12, or who had finished school recently.

\section{Results}

The three research questions posed for the study were addressed using a combination of descriptive statistics, chi-square, and multivariate analysis of variance (MANOVA) procedures. Significant MANOVA effects were followed with univariate analyses of variance (ANOVAs), interpreted using Holm-Bonferroni adjusted alpha levels (Holm, 1979). Two participants' responses were excluded for all analyses performed aside from those related to Research Question 1, which pertained specifically to the issue of subject choice. This was because, in other parts of the survey, these participants took under five seconds to respond to each item, which was deemed insufficient time to consider the questions with due care. Thus, 84 cases were retained to address Research Question 1, and 82 cases for Research Questions 2 and 3. Prior to conducting the former type of analysis, a series of data screening runs was performed to ensure conformity to the underlying assumptions of normality, linearity, outliers, univariate and multivariate homogeneity of variance. Despite some evidence of skew in some variables, given the robustness of the procedures to deviations associated with non-normality, all of these analyses produced satisfactory results.

\subsection{Research Question 1: What Year 11 mathematics course choices did Year 10 boys and girls of different achievement levels make?}

The comparison of participant course selections with teachers' course recommendations resulted in five clusters of participants, namely:

1. Standard achievement under-aspiring (recommended Standard, chose no mathematics)

2. Standard achievement aligned (recommended Standard, chose Standard)

3. Standard achievement over-aspiring (recommended Standard, chose Advanced)

4. Advanced achievement under-aspiring (recommended Advanced, chose Standard)

5. Advanced achievement aligned (recommended Advanced, chose Advanced) 
An Advanced achievement over-aspiring cluster was not possible in this study as the sample school did not offer students a higher mathematics option beyond the Advanced pathway. The distribution of girls and boys by achievement group and course choice is shown in Table 1. From Table 1, the percentages of girls and boys was similar for the two aligned groups, although 5.5\% more Advanced achievement boys chose to select an Advanced aligned choice than Advanced girls. The percentages of girls and boys differed markedly; however, both for the over-aspiring Standard achievement group (4.35\% of girls vs. $15.79 \%$ of boys) and for both the under-aspiring groups. Over twice as many Standard achievement girls as boys under-aspired to "no mathematics" $(10.87 \%$ of girls, vs $5.26 \%$ of boys). No boys in the Advanced achievement group under-aspired, while $13.04 \%$ of Advanced achievement girls under-aspired. Based on these results, students' choices predominantly aligned with their teachers' views of their achievement levels. Amongst those that did not align; however, boys showed a stronger tendency to over-aspire, while girls showed a stronger tendency to under-aspire.

Table 1. Number of boys and girls by achievement group and course choice

\begin{tabular}{llll}
\hline \multirow{2}{*}{ Achievement group } & Cluster & Gender & \\
\cline { 3 - 4 } & & Girls & Boys \\
\hline \multirow{3}{*}{ Standard } & Under-aspiring (chose no mathematics) & $5(10.87 \%)$ & $2(5.26 \%)$ \\
& Aligned (chose Standard) & $21(45.65 \%)$ & $18(47.37 \%)$ \\
& Over-aspiring (chose Advanced) & $2(4.35 \%)$ & $6(15.79 \%)$ \\
\hline \multirow{2}{*}{ Advanced } & Under-aspiring (chose Standard) & $6(13.04 \%)$ & $0(0 \%)$ \\
& Aligned (chose Advanced) & $12(26.08 \%)$ & $12(31.58 \%)$ \\
& Total & $46(100.0 \%)$ & $38(100.0 \%)$ \\
\hline
\end{tabular}

3.2 Research Question 2: Controlling for achievement level, do boys and girls differ in their mathematics self-perceptions, perceptions of the value of mathematics, and in their perceptions of mathematics as a subject area?

Descriptive statistics for all subscale variables included in the analyses conducted to address Research Question 2 are shown in Table 2. Participants' results were analysed according to achievement group and gender: Standard girl $(n=27)$, Standard boy $(n=25)$, Standard total $(n=52)$, Advanced girl $(n=18)$, Advanced boy $(n=12)$, Advanced total $(n=30)$, Total girl $(n=45)$, Total boy $(n=37)$, Total participants $(n=82)$. To determine whether there were significant differences across boys and girls as a whole, and whether the magnitude or direction of this difference varied across achievement groups, a 2 (gender) by 2 (achievement group) MANOVA was performed, including all of the EVT-based subscales, as well as sense of belonging, gender bias, growth mindset, and perceptions of the status of mathematics as a subject area. Based on the Pillai's trace criterion (used owing to the relatively low sample size, see Tabachnick \& Fidell, 2013), there was a significant main effect for achievement group, $V=.42$, $F(10,69)=5.08, p=.00002$, as well as for gender $V=.33, F(10,69)=3.33, p=.001$. There was; however, no significant multivariate interaction effect, $V=.12, F(10,69)<1, p=.47$. This result suggests that on the linear composite dependent variable, there was a significant overall difference, both across achievement groups and genders, but that the difference between genders was robust across the achievement groups (and vice versa).

Univariate analyses of variance (ANOVAs) on each of the individual subscales indicated that the main effect of achievement group was significant for all subscales apart from gender bias, growth mindset, and mathematics status, $F \mathrm{~s}(1,78) \geq 10.23, p \mathrm{~s} \leq .002$, partial $\eta^{2} \geq .12$. The gender main effect was significant for all subscales apart from utility value - school, attainment value, and gender bias, $F \mathrm{~s}(1,78) \geq 8.59, p \mathrm{~s} \leq .004$, partial $\eta^{2} \geq .10$. Based on the means shown in Table 2, these results indicated that boys were higher than girls on intrinsic value, utility value - general, self-concept, and sense of belonging. They also held a stronger growth mindset and had a stronger tendency to see mathematics as a high-status subject. 
Table 2. Descriptive statistics mean scores for self-perceptions, perceptions of the value of mathematics, and perceptions of mathematics as a subject area

\begin{tabular}{|c|c|c|c|c|}
\hline & \multirow{2}{*}{ Achievement group } & \multicolumn{2}{|l|}{ Gender } & \multirow{2}{*}{ Total } \\
\hline & & Girl & Boy & \\
\hline \multirow{3}{*}{ Intrinsic value subscale score } & Standard & $3.96(1.60)$ & $5.24(2.02)$ & $4.57(1.91)$ \\
\hline & Advanced & $5.70(1.69)$ & $6.83(1.72)$ & $6.15(1.72)$ \\
\hline & Total & $4.65(1.83)$ & $5.76(2.05)$ & $5.15(2.00)$ \\
\hline \multirow{3}{*}{ Attainment value subscale score } & Standard & $4.53(1.83)$ & $5.38(1.93)$ & $4.94(1.91)$ \\
\hline & Advanced & $6.72(1.65)$ & $6.95(1.84)$ & $6.81(1.70)$ \\
\hline & Total & $5.40(2.05)$ & $5.89(2.02)$ & $5.62(2.04)$ \\
\hline \multirow{3}{*}{ Utility value - school subscale score } & Standard & $5.63(1.91)$ & $5.95(1.98)$ & $5.78(1.93)$ \\
\hline & Advanced & $8.07(1.39)$ & $7.90(1.62)$ & $8.00(1.46)$ \\
\hline & Total & $6.61(2.09)$ & $6.58(2.07)$ & $6.59(2.07)$ \\
\hline \multirow{3}{*}{ Utility value - general subscale score } & Standard & $3.87(2.02)$ & $5.31(2.33)$ & $4.56(2.27)$ \\
\hline & Advanced & $5.71(2.36)$ & $7.77(1.48)$ & $6.53(2.27)$ \\
\hline & Total & $4.61(2.32)$ & $6.11(2.37)$ & $5.28(2.45)$ \\
\hline \multirow{3}{*}{ Self-concept subscale score } & Standard & $4.91(1.60)$ & $5.61(1.42)$ & $5.25(1.54)$ \\
\hline & Advanced & $6.04(1.77)$ & $7.90(1.56)$ & $6.79(1.90)$ \\
\hline & Total & $5.36(1.74)$ & $6.35(1.81)$ & $5.81(1.83)$ \\
\hline \multirow{3}{*}{ Sense of belonging subscale score } & Standard & $4.36(1.53)$ & $5.95(1.84)$ & $5.12(1.85)$ \\
\hline & Advanced & $5.77(1.63)$ & $6.98(1.47)$ & $6.25(1.66)$ \\
\hline & Total & $4.92(1.70)$ & $6.29(1.77)$ & $5.54(1.86)$ \\
\hline \multirow{3}{*}{ Gender bias - single item } & Standard & $5.70(1.07)$ & $6.04(1.43)$ & $5.87(1.25)$ \\
\hline & Advanced & $5.50(1.69)$ & $5.92(0.29)$ & $5.67(1.32)$ \\
\hline & Total & $5.62(1.34)$ & $6.00(1.18)$ & $5.79(1.27)$ \\
\hline \multirow{5}{*}{ Growth mindset -single item } & Standard & $5.22(2.89)$ & $7.24(1.99)$ & $6.19(2.67)$ \\
\hline & Advanced & $6.39(2.40)$ & $7.83(2.82)$ & $6.97(2.63)$ \\
\hline & Total & $5.69(2.74)$ & $7.43(2.27)$ & $6.48(2.67)$ \\
\hline & Advanced & $3.00(2.11)$ & $5.25(2.86)$ & $3.90(2.64)$ \\
\hline & Total & $2.89(2.09)$ & $4.89(2.64)$ & $3.79(2.55)$ \\
\hline
\end{tabular}

Note. Standard deviations appear in parentheses after means.

\subsection{Research Question 3: What sociocultural factors influenced girls' and boys' of different achievement levels} mathematics course choices?

Descriptive statistics for the sociocultural values are shown in Table 3. The MANOVA on these scores indicated that there was a significant multivariate main effect for achievement group, $V=.26, F(9,70)=2.74, p=.008$. There was; however, no significant multivariate main effect for gender $V=.079, F(9,70)<1$, and no significant multivariate gender by achievement group interaction effect, $V=.195, F(9,70)=1.88, p=.07$. Given that the interaction effect did approach significance at the .05 level, the univariate ANOVAs were examined to determine which of the specific variables were involved in this borderline effect. The univariate ANOVAs indicated a marginally significant interaction effect for the questions, How important were parents in influencing you?, $F(1,78)$ $=7.44, p=.008$, partial $\eta^{2}=.09$, How important were brothers/sisters in influencing you?, $F(1,43)=9.57, p=.003$, partial $\eta^{2}=.18$, and, to a more marginal extent, How important were teachers in influencing you?, $F(1,78)=4.25$, $p=.04$, partial $\eta^{2}=.05$. The relative scores for girls and boys separately for each source of sociocultural influence are shown in Table 3. 
Based on the means for boys and girls in each achievement group across these three variables, for the question, How important were parents in influencing you?, in the Standard achievement group, the mean score for girls was higher than for boys. In the Advanced group, however, the mean score for girls was lower than for boys. For the question, How important were brothers/sisters in influencing you?, in the Standard achievement group, the mean score for girls was higher than for boys, but in the Advanced group, the mean score for girls was lower than for boys. For the question, How important were teachers in influencing you?, in the Standard achievement group, the mean score for girls was higher than for boys, but in the Advanced group, the mean score for girls was lower than for boys. It is clear from these results that boys in the Advanced achievement group reported being more heavily influenced by all three of these sources in their subject choices than were girls in the Advanced achievement group. In the Standard achievement group, girls reported being more heavily influenced by these sources than boys.

Table 3. Descriptive statistics for sociocultural influences

\begin{tabular}{|c|c|c|c|c|}
\hline & \multirow{2}{*}{ Achievement Group } & \multicolumn{2}{|l|}{ Gender } & \multirow[b]{2}{*}{ Total } \\
\hline & & Girl & Boy & \\
\hline \multirow{3}{*}{ Parents } & Standard & $6.67(2.90)$ & $5.16(2.76)$ & $5.94(2.91)$ \\
\hline & Advanced & $5.94(2.76)$ & $7.83(1.64)$ & $6.70(2.52)$ \\
\hline & Total & $6.38(2.83)$ & $6.03(2.74)$ & $6.22(2.78)$ \\
\hline \multirow{3}{*}{ Older siblings } & Standard & $3.85(3.26)$ & $2.52(2.33)$ & $3.21(2.90)$ \\
\hline & Advanced & $4.56(3.57)$ & $6.92(3.53)$ & $5.50(3.68)$ \\
\hline & Total & $4.13(3.36)$ & $3.95(3.43)$ & $4.05(3.37)$ \\
\hline \multirow{3}{*}{ Other family members } & Standard & $2.59(2.26)$ & $3.04(2.65)$ & $2.81(2.44)$ \\
\hline & Advanced & $2.00(2.00)$ & $2.83(2.29)$ & $2.33(2.12)$ \\
\hline & Total & $2.36(2.16)$ & $2.97(2.51)$ & $2.63(2.33)$ \\
\hline \multirow{3}{*}{ Friends } & Standard & $3.89(2.68)$ & $3.04(2.34)$ & $3.48(2.53)$ \\
\hline & Advanced & $5.00(2.85)$ & $5.50(2.58)$ & $5.20(2.71)$ \\
\hline & Total & $4.33(2.77)$ & $3.84(2.65)$ & $4.11(2.71)$ \\
\hline \multirow{3}{*}{ Older students } & Standard & $3.96(2.99)$ & $3.88(2.71)$ & $3.92(2.83)$ \\
\hline & Advanced & $6.28(2.93)$ & $5.92(2.68)$ & $6.13(2.79)$ \\
\hline & Total & $4.89(3.15)$ & $4.54(2.83)$ & $4.73(3.10)$ \\
\hline \multirow{3}{*}{ Teachers } & Standard & $6.44(2.44)$ & $5.32(2.81)$ & $5.90(2.66)$ \\
\hline & Advanced & $6.61(2.95)$ & $8.00(2.00)$ & $7.17(2.67)$ \\
\hline & Total & $6.51(2.63)$ & $6.19(2.84)$ & $6.37(2.72)$ \\
\hline \multirow{3}{*}{$\begin{array}{l}\text { Someone you don't know } \\
\text { personally }\end{array}$} & Standard & $2.11(2.68)$ & $2.04(1.90)$ & $2.08(2.32)$ \\
\hline & Advanced & $2.22(2.26)$ & $2.42(2.88)$ & $2.30(2.48)$ \\
\hline & Total & $2.16(2.50)$ & $2.16(2.23)$ & $2.16(2.37)$ \\
\hline \multirow{3}{*}{$\begin{array}{l}\text { Someone famous or a role } \\
\text { model }\end{array}$} & Standard & $1.59(1.89)$ & $2.04(2.40)$ & $1.81(2.13)$ \\
\hline & Advanced & $1.94(2.07)$ & $1.75(1.49)$ & $1.87(1.83)$ \\
\hline & Total & $1.73(1.95)$ & $1.95(2.12)$ & $1.83(2.02)$ \\
\hline \multirow{3}{*}{ Media } & Standard & $1.37(0.79)$ & $2.12(1.92)$ & $1.73(1.48)$ \\
\hline & Advanced & $1.61(1.46)$ & $2.25(2.30)$ & $1.87(1.83)$ \\
\hline & Total & $1.47(1.10)$ & $2.16(2.02)$ & $1.78(1.61)$ \\
\hline
\end{tabular}

Note. Standard deviations appear in parentheses after means. 


\section{Discussion}

The results related to Research Question 1 in this study indicated that, while girls deemed capable by their teachers of undertaking advanced mathematics courses tended to under-aspire (i.e., select less advanced courses), the opposite pattern was true for boys. While the results of this study are based on a small number of participants from one school, they echo national statistics that show that higher-achieving girls are less likely to enrol in advanced Year 11 and12 mathematics courses than higher-achieving boys (Li \& Koch, 2017). Despite the fact that teachers in this study viewed girls more frequently than boys to be capable of undertaking the advanced courses, fewer girls than boys chose to do so, highlighting the on-going problem of the underrepresentation of girls in higher mathematics courses.

The results related to Research Question 2 indicated that boys had higher scores in mathematics self-concept than girls in both achievement groups. This result is aligned with findings from larger studies which indicate reduced feelings of efficacy and competence in girls relative to boys when considering mathematics as a subject (Hyde, 2015; Parker, Van Zanden, \& Parker, 2018; Sax, Kanny, Riggers-Pieh, Whang, \& Paulson, 2015). Previous studies have shown mathematics self-concept to be a predictive factor in subsequent mathematics course selections (OECD, 2012; McPhan, Morony, Pegg, Cooksey, \& Lynch, 2008). Further investigation of the role of mathematics self-concept in gendered choices is important, especially as previous research has indicated a tendency for girls to underestimate their mathematical abilities (Assouline, Colangelo, Ihrig, \& Forstadt, 2006; Nokelainen, Tirri, \& Merenti-Välimäki, 2007).

Girls' and boys' perceptions of the subjective task value of mathematics in this study differed as anticipated according to the research literature. Boys ascribed significantly more intrinsic value to mathematics than girls, irrespective of achievement group. This finding is in line with those reported in various previous studies (Frenzel et al., 2010; Gaspard et al., 2015; Lazarides \& Ittel, 2013; Watt, 2016). Some researchers have suggested that high achievement is more important for girls than boys in maintaining an interest in STEM disciplines (Holmes, Gore, Smith, \& Lloyd, 2018). However, for a number of girls in this study, having high achievement in mathematics did not necessarily equate to being more interested in mathematics, nor to selecting a challenging mathematics course. This is an important finding worthy of further research with a larger participant group.

In accordance with previous studies (for example, Watt et al., 2012), fewer differences were noted between the results of girls and boys in terms of attainment value. However, gender differences were found in aspects of utility value. While there were no significant differences between girls and boys in the perceived utility of mathematics in enhancing their school results (utility value-school), girls were significantly less concerned than boys with general utility value considerations. These results are aligned with recent findings by Gaspard et al. (2015), and Fadda et al. (2019), which indicated differences in girls' and boys' perceptions of the general or future utility of mathematics, but not in terms of its utility for school performance. Fadda et al. suggested that girls view mathematics as being important in the school context but consider it less important in terms of their own future goals. Research on approaches to increase girls' appreciation of the utility of higher mathematics courses for future life is warranted if they are to be encouraged to study these courses in greater numbers.

Turning to girls' and boys' perceptions of mathematics as a subject area, the findings of this study with respect to sense of belonging in mathematics classrooms indicated that girls showed a significantly lower sense of belonging than boys. This is not surprising considering the body of research suggesting that girls may perceive the mathematics classroom as less welcoming than boys (for example, Cheryan, 2012). This may result in a lowered sense of personal value and acceptance within the mathematics domain, as also noted in previous studies (Good et al., 2012; Gunderson et al., 2012; Pietri et al., 2019). Given the importance of sense of belonging in predicting key subject-related outcomes such as engagement and subject choice (for example, Good, 2012), this finding would suggest that further empirical investigation in school-age populations would be recommended.

The results from the survey with respect to growth versus fixed mindset orientations also align with the findings of previous studies indicating that girls hold more fixed mindset views than boys (Hwang et al., 2019; Seo et al., 2019). Irrespective of mathematics achievement level, girls had a stronger tendency than boys to take the view that some people are born with mathematics ability, as opposed to the alternative perspective that mathematics ability can be learned. This is concerning, given the associations that have now been reported between academic mindsets, achievement and STEM career aspirations (Degol et al., 2018; Huang, Zhang, \& Hudson, 2018; Hwang et al., 2019).

In this study, girls had a somewhat more balanced view of the relative status of mathematics in comparison to other subject areas than boys. It is unclear based on the question posed in this study whether this indicated that girls saw mathematics more negatively than boys, or whether they viewed other subjects as equally important. Previous 
studies evaluating the career preferences of individuals with high mathematical ability have shown that those with equally high verbal and mathematical ability are more likely to select a non-STEM pathway than those with a relative strength in the mathematics domain (Wang \& Degol, 2013; Wang, Ye, \& Degol, 2017). If it is the case that females tend to show higher verbal abilities to males of similar mathematical abilities (Wang, Eccles, \& Kenny, 2013), it is possible that mathematically capable girls with strong verbal skills will place a higher value on humanities subjects as a result (Eccles \& Wang, 2016).

One area in which no gender differences were found was in terms of gender bias. The mean scores for girls and boys were close to a neutral position on whether girls or boys were viewed by participants as being stronger mathematics students. Neutral beliefs about gender differences in mathematics have been noted in prior studies as not unusual for adolescents (Passolunghi, Rueda Ferreira, \& Tomasetto, 2014). Two possible explanations have been offered. First, older school students may be aware of the undesirability of gender biased attitudes and may censor their responses accordingly. Second, these students may not be consciously aware of implicit and automatic stereotypical associations which link males more than females to mathematics. This implicit bias may be still be present in individuals who outwardly reject mathematics gender stereotypes (Hill, Corbett, \& St. Rose, 2010; Passolunghi et al., 2014; Steffens, Jelenec, \& Noack, 2010). As the present study relied wholly on self-report data, it is therefore possible that the neutral finding for gender bias does not fully reflect participants' true perceptions.

With respect to Research Question 3, findings revealed a potential gender disparity in the perceived influence of parents, siblings, and teachers across achievement groups. Boys in both the Standard and Advanced achievement groups perceived parents, siblings, and teachers to be somewhat more influential in their mathematics course choices than girls in either achievement group. This result should, however, be interpreted with some caution, due to the sample size and the fact that the result only approached significance at the .05 level. Even so, previous research has documented the importance of parents and teachers on the mathematics course selections of both girls and boys (Degol et al., 2017; Gunderson et al., 2012; Legewie \& DiPrete, 2012). However, further research is needed to evaluate more specifically whether girls and boys are subject to different kinds of sociocultural influence.

\section{Limitations}

One limitation of this study is that it focused only on participants from one school. It is possible that different findings may be obtained from participants from other schools in WA. Given the relatively small study sample, group comparisons were based on small numbers in some cases, and this inevitably imposes restrictions on the generality of the study. A further caveat is that the perceived influence of teachers is based upon a small group of mathematics teachers. Participants from different schools may view the influence of teachers differently. A larger sample of students from a range of schools would also provide more generalisable data in terms of sociocultural influences on student choice. In addition, this study explored self-perceptions in relation to the study of mathematics generally and did not address the perceived benefits associated with specific mathematics courses in comparison to each other. This could be investigated in further research as it remains likely that students consider the advantages of studying particular courses over others when making mathematics course selections. Finally, the findings of the present study are limited by the cross-sectional nature of the data. As such, it is not possible to ascertain whether participants changed their stated future mathematics course prior to starting their Year 11 studies. Future research could investigate whether any such shifts in intentions are influenced by self-perceptions, perceptions about the study of mathematics, or sociocultural factors.

\section{Conclusion}

It is important to note that there is likely to be a complex interplay amongst the various beliefs and perceptions demonstrated by girls and boys in this study. In particular, it has been found in previous research that the different perceptions studied here can compound and exacerbate one another. For example, recent studies have indicated that having a fixed mindset in mathematics can make girls more susceptible to developing a lower self-concept (Degol et al., 2018), a decreased sense of belonging and poorer performances when faced with difficulties, especially in environments where stereotypes are perceived to exist (Hwang et al., 2019). Thus, girls' overall tendency to under-aspire may be a product not of one particular perception or belief, but of an overall profile in which different negative beliefs compound others. In light of this, addressing the issue of girls' propensity to under-aspire when selecting mathematics courses is likely to require a multi-faceted approach.

\section{References}

Assouline, S. G., Colangelo, N., Ihrig, D., \& Forstadt, L. (2006). Attributional choices for academic success and failure by intellectually gifted students. Gifted Child Quarterly, 50(4), 283-294. 
https://doi.org/10.1177/001698620605000402

Bandura, A., \& Bussey, K. (2004). On broadening the cognitive, motivational, and sociostructural scope of theorizing about gender development and functioning: Comment on Martin, Ruble, and Szkrybalo (2002). Psychological Bulletin, 130(5), 691-701. https://doi.org/10.1037/0033-2909.130.5.691

Barrington, F. \& Evans, M. (2014). Participation in Year 12 mathematics 2004-2014. Retrieved from http://amsi.org.au/publications/participation-in-year-12-mathematics-2004-2014/

Barron, K., \& Hulleman, C. (2014). Expectancy-Value-Cost Model of Motivation. https://doi.org/10.1016/B978-0-08-097086-8.26099-6

Blackwell, L., Trzesniewski, K., \& Dweck, C. S. (2007). Implicit theories of intelligence predict achievement across an adolescent transition: A longitudinal study and an intervention. Child Development, 78, 246-263. https://doi-org.ezproxy.library.uwa.edu.au/10.1111/j.1467-8624.2007.00995.x

Bleazby, J. (2015). Why some school subjects have a higher status than others: The epistemology of the traditional curriculum hierarchy. Oxford Review of Education, 41(5), 671-689. https://doi.org/10.1080/03054985.2015.1090966

Blickenstaff, J. (2005). Women and science careers: Leaky pipeline or gender filter? Gender \& Education, 17(4), 369-386. https://doi.org/10.1080/09540250500145072

Bosch, O., Revilla, M., Decastellarnau, A., \& Weber, W. (2019). Measurement reliability, validity, and quality of slider versus radio button scales in an online probability-based panel in Norway. Social Science Computer Review, 37(1), 119-132. https://doi.org/10.1177/0894439317750089

Breakwell, G., Vignoles, V., \& Robertson, T. (2003). Stereotypes and crossed-category evaluations: The case of gender and science education. British Journal of Psychology, 94(4), 437-55. https://doi.org/10.1348/000712603322503024.

Broadley, K. (2015). Entrenched gendered pathways in science, technology, engineering and mathematics: Engaging girls through collaborative career development. Australian Journal of Career Development, 24(1), 27-38. https://doi.org/10.1177/1038416214559548

Chen, A., \& Liu, X. (2009). Task values, cost, and choice decisions in college physical education. Journal of Teaching in Physical Education, 28, 192-213. https://doi.org/10.1123/jtpe.28.2.192

Cheryan, S. (2012). Understanding the paradox in math-related fields: Why do some gender gaps remain while others do not? Sex Roles, 66, 184-190. https://doi.org/10.1007/s11199-011-0060-z

Degol, J. L., Wang, M. -T., Ye, F., \& Zhang, C. (2017). Who makes the cut? Parental involvement and maths trajectories predicting college enrolment. Journal of Applied Developmental Psychology, 50, 60-70. https://doi.org/10.1016/j.appdev.2017.03.007

Degol, J., Wang, M., Zhang, Y., \& Allerton, J. (2018). Do growth mindsets in math benefit females? Identifying pathways between gender, mindset, and motivation. Journal of Youth and Adolescence, 47(5), 976-990. https://doi.org/10.1007/s10964-017-0739-8

Dweck, C. S. (2006). Mindset: The new psychology of success. New York, NY: Random House.

Dweck, C. S. (2013). Self-theories, their role in motivation, personality and development. London: Taylor and Francis.

Dweck, C. S., \& Leggett, E. L. (1988). A social-cognitive approach to motivation and personality. Psychological Review, 95, 256-273. https://doi.org/10.1037/0033-295X.95.2.256

Dweck, C. S., Chiu, C. Y., \& Hong, Y. Y. (1995). Implicit theories and their role in judgments and reactions: A word from two perspectives. Psychological Inquiry, 6, 285. https://doi.org/10.1207/s15327965pli0604_1

Eccles, J. S. (1987). Gender roles and women's achievement-related decisions. Psychology of Women Quarterly, 11(2), 135-172. https://doi.org/10.1111/j.1471-6402.1987.tb00781.x

Eccles, J. (2009). Who am I and what am I going to do with my life? Personal and collective identities as motivators of action. Educational Psychologist, 44(2), 78-89. https://doi.org/10.1080/00461520902832368

Eccles, J., Adler, T. F., Futterman, R., Goff, S. B., Kaczala, C. M., Meece, J., \& Midgley, C. (1983). Expectancies, values and academic behaviors. In Spence, J. T. (ed.) Achievement and achievement motives, W. H. Freeman: 
San Francisco.

Eccles, J. S., O’Neill, S. A., \& Wigfield, A. (2005). Ability self-perceptions and subjective task values in adolescents and children. In K. A. Moore and L. H. Lipmann (Eds.), What do children need to flourish? Conceptualizing and measuring indicators of positive development (pp.237-249). New York, NY: Springer. https://doi.org/10.1007/0-387-23823-9_15

Eccles, J. S., \& Wang, M.-T. (2016). What motivates females and males to pursue careers in mathematics and science? International Journal of Behavioral Development, 40(2), 100-106. https://doi.org/10.1177/0165025415616201

Eccles, J. S., \& Wigfield, A. (2002). Motivational beliefs, values and goals. Annual Review of Psychology, 53, 109-32. https://doi.org/10.1146/annurev.psych.53.100901.135153

Ernest, J. B., Reinholz, D. L., \& Shah, N. (2019). Hidden competence: women's mathematical participation in public and private classroom spaces. Educational Studies in Mathematics, 102, 153-172. https://doi.org/10.1007/s10649-019-09910-w

Fadda, D., Scalas, L., Morin, A., Marsh, H., \& Gaspard, H. (2019). Value beliefs about math: A bifactor-ESEM representation. European Journal of Psychological Assessment. https://doi.org/10.1027/1015-5759/a000513

Flake, J. K., Barron, K. E., Hulleman, C., McCoach, B. D., \& Welsh, M. E. (2015). Measuring cost: The forgotten component of expectancy-value theory. Contemporary Educational Psychology, 1, 232-244. https://doi.org/10.1016/j.cedpsych.2015.03.002

Francis, B., Archer, L., Moote, J., de Witt, J., \& Yeomans, L. (2017). Femininity, science, and the denigration of the girly girl. British Journal of Sociology of Education, 38(8), 1097-1110. https://doi.org/10.1080/01425692.2016.1253455

Francis, B., Mills, M., \& Lupton, R. (2017). Towards social justice in education: contradictions and dilemmas. Journal of Education Policy, 32(4), 414-431. https://doi.org/10.1080/02680939.2016.1276218

Frenzel, A.C., Goetz, T., Pekrun, R., \& Watt, H. M. G. (2010). Development of mathematics interest in adolescence: Influences of gender, family, and school context. Journal of Research on Adolescence, 20(2), 507-537. https://doi.org/10.1111/j.1532-7795.2010.00645.x

Gaspard, H., Dicke, A., Flunger, B., Schreier, B., Häfner, I., Trautwein, U., \& Nagengast, B. (2015). More value through greater differentiation: Gender differences in value beliefs about math. Journal of Educational Psychology, 107(3), 663-677. https://doi.org/10.1037/edu0000003

Gemici, S., Bednarz, A., Karmel, T., \& Lim, P. (2014). Parental influences drive young people's educational aspirations, NCVER, Adelaide.

Good, C. (2012). Reformulating the talent equation: Implications for gifted students' sense of belonging and achievement. In R. F. Subotnik, A. Robinson, \& C. M. Callahan (Eds.), Malleable minds: Translating insights from psychology and neuroscience to gifted education (pp. 37-54). Storrs, CT: The National Research Center on the Gifted and Talented, University of Connecticut.

Good, C., Rattan, A., \& Dweck, C. S. (2012). Why do women opt out? Sense of belonging and women's representation in mathematics. Journal of Personality and Social Psychology, 102(4), 700-717. https://doi.org/10.1037/a0026659

González, A. Paoloni, P-V., Donolo, D., \& Rinaudo, C. (2015). Behavioral engagement and disaffection in school activities: Exploring a model of motivational facilitators and performance outcomes. Annals of Psychology, 31(3), 869-878. https://doi.org/10.6018/analesps.31.3.176981

Gunderson, E. A., Ramirez, G., Levine, S. C., \& Beilock, S. L. (2012). The role of parents and teachers in the development of gender-related math attitudes. Sex Roles, 66(3-4), 153-166. https://doi.org/10.1007/s11199-011-9996-2

Guo, J., Parker, P. D., Marsh, H. W., \& Morin, A. J. S. (2015). Achievement, motivation, and educational choices: A longitudinal study of expectancy and value using a multiplicative perspective. Developmental Psychology, 51(8), 1163-1176. https://doi.org/10.1037/a0039440

Hattie, J. (2009). Visible learning: a synthesis of over 800 meta-analyses relating to achievement. London: Routledge. https://doi.org/10.4324/9780203887332

Hill, C., Corbett, C., \& St.Rose, A. (2010). Why sf Few? Women in science, technology, engineering, and 
mathematics. American Association of University Women.

Hobbs, L., Jakab, C., Millar. V., Prain, V., Redman, C., Speldewinde., Tytler, R., \& van Driel, J. (2017). Girls' future - our future: The Invergowrie foundation STEM report. Melbourne.

Holm, S. (1979). A simple sequentially rejective multiple test procedure. Scandinavian Journal of Statistics, 6(2), 65-70.

Holmes, K., Gore, J., Smith, M., \& Lloyd, A. (2018). An integrated analysis of school students' aspirations for STEM careers: which student and school factors are most predictive? International Journal of Science and Mathematics Education, 16(4), 655-675. https://doi.org/10.1007/s10763-016-9793-z

Huang, X., Zhang, J., \& Hudson, L. (2018). Impact of math self-efficacy, math anxiety, and growth mindset on math and science career interest for middle school students: the gender moderating effect. European Journal of Psychology of Education. https://doi.org/10.1007/s10212-018-0403-z

Hwang, N. A., Reyes, M., \& Eccles, J. S. (2019). Who holds a fixed mindset and whom does it harm in mathematics? Youth \& Society, 51(2), 247-267. https://doi.org/10.1177/0044118X16670058

Hyde, J. (2015). Gender similarities and differences. Annual Review of Psychology, 65, 373-398. https://doi.org/10.1146/annurev-psych-010213-115057

Jeffries, D., Curtis, D. D., \& Conner, L. N. (2019). Student factors influencing STEM subject choice in Year 12: a structural equation model using PISA/LSAY data. International Journal of Science and Mathematics Education, 18(3), 441-461. https://doi.org/10.1007/s10763-019-09972-5

Jensen, B., Sonnemann, J., Roberts-Hull, K., \& Hunter, A. (2016). Beyond PD: Teacher professional learning in high-performing systems. Washington, DC: National Center on Education and the Economy. Levine, T.H. \& Marcus, A.S.

Kirkham, J., Chapman, E., \& Wildy, H. (2019). Factors considered by Western Australian Year 10 students in choosing Year 11 mathematics courses. Mathematics Education Research Journal. Advanced online publication. https://doi.org/10.1007/s13394-019-00277-y

Korpershoek, H., Guntern, S., \& van der Werf, G. (2014). The impact of significant others on gender-atypical, gender-typical, and gender-neutral study choices. Gruppendyn Organisationsberat, 45, 441-463. https://doi.org/10.1007/s11612-014-0263-1

Lazarides, R., \& Ittel, A. (2013). Mathematics interest and achievement: What role do perceived parent and teacher support play? A longitudinal analysis. International Journal of Gender, Science and Technology, 5, 207-231.

Lazarides, R., Rubach, C., \& Ittel, A. (2017). Adolescents' perceptions of socializers' beliefs, career related conversations, and motivation in mathematics. Developmental Psychology, 53(3), 525-539. https://doi.org/10.1037/dev0000270

Li, N., \& Koch, I. (2017). Choose maths gender report: Participation, performance, and attitudes towards mathematics. Melbourne: Australian Mathematical Sciences Institute. Retrieved from https://amsi.org.au/?publications=gender-report-2017-participation-performance-attitudes-towards-mathema tics

Leder, G. C., Forgasz, H. J., \& Jackson, G. (2014). Mathematics, English and gender issues: Do teachers count? Australian Journal of Teacher Education, 39(9), 18-34. https://doi.org/10.14221/ajte.2014v39n9.3

Legewie, J., \& DiPrete, T. A. (2012). School context and the gender gap in educational achievement. American Sociological Review, 77(3), 463-485. https://doi.org/10.1177/0003122412440802

Leslie, S-J., Cimpian, A., Meyer, M., \& Freeland, E. (2015). Expectations of brilliance underlie gender

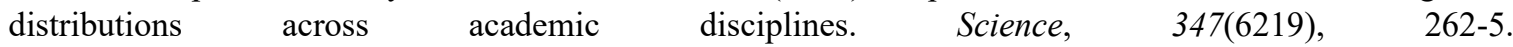
https://doi.org/10.1126/science.1261375

Marsh, H. W. (2007). Self-concept theory, measurement and research into practice: The role of self-concept in educational psychology. London, England: British Psychological Society.

Marsh, H., Pekrun, R., Parker, P., Murayama, K., Guo, J., Dicke, T., \& Arens, A. (2018). The murky distinction between self-concept and self-efficacy: Beware of lurking jingle-jangle fallacies. Journal of Educational Psychology, 111(2), 331-353. https://doi.org/10.1037/edu0000281

Martin, A. J., Anderson, J., Bobis, J., Way, J., \& Vellar, R. (2012). Switching on and switching off in mathematics. An ecological study of future intent and disengagement amongst middle school students. Journal of 
Educational Psychology, 104(1), 1-18. https://doi.org/10.1037/a0025988

Martin, A.J., \& Lazdendic, G. (2018). Achievement in large-scale national numeracy assessment: An ecological study of motivation and student, home, and school predictors. Journal of Educational Psychology, 110(4), 465-482. https://doi.org/10.1037/edu0000231

Martin, A. J., Way, J., Bobis, J., \& Anderson, J. (2015). Exploring the ups and downs of mathematics engagement in the middle years of school. The Journal of Early Adolescence, 35(2), 199-244. https://doi.org/10.1177/0272431614529365

McPhan, G., Morony, W., Pegg, J., Cooksey, R., \& Lynch, T. (2008). Maths? Why Not? Canberra: Department of Education, Employment and Workplace Relations.

Nagy, G., Trautwein, U., Baumert, J., Köller, O., \& Garrett, J. (2006). Gender and course selection in upper secondary education: Effects of academic self-concept and intrinsic value. Educational Research and Evaluation, 12(4), 323-345. https://doi.org/10.1080/13803610600765687

Nokelainen, P., \& Tirri, K., \& Merenti-Välimäki, H-L. (2007). Investigating the influence of attribution styles on the development of mathematical talent. Gifted Child Quarterly, 51(1), 64-81. https://doi.org/10.1177/0016986206296659

Mullis, I.V.S., Martin, M.O., Foy, P., \& Arora, A. (2012). TIMSS 2011 International Results in Mathematics. TIMSS \& PIRLS International Study Center, Boston College, Chestnut Hill, MA. Retrieved from https://files.eric.ed.gov/fulltext/ED544554.pdf

OECD. (2012). PISA 2012 results. Retrieved from http://www.oecd.org/Organization for Economic Cooperation and Development. (2016). PISA 2012 results. Retrieved from http://www.oecd.org/

Parker, P. D., Van Zanden, B., \& Parker, R. B. (2018). Girls get smart, boys get smug: Historical changes in gender differences in math, literacy, and academic social comparison and achievement. Learning and Instruction, 54, 125-137. https://doi.org/10.1016/j.learninstruc.2017.09.002

Passolunghi, M. C., Rueda Ferreira, T. I., \& Tomasetto, C. (2014). Math-gender stereotypes and math-related beliefs in childhood and early adolescence. Learning and Individual Differences, 34, 70-76. https://doi.org/10.1016/j.lindif.2014.05.005

Pietri, E., Hennes, E., Dovidio, J., Brescoll, V., Bailey, A., Moss-Racusin, C., \& Handelsman, J. (2019). Addressing unintended consequences of gender diversity interventions on women's sense of belonging in STEM. Sex Roles, 80(9), 527-547. https://doi.org/10.1007/s11199-018-0952-2

Quaglia, R., Giovanna, F., Gastaldi, M., Prino, L. E., Pasta, T., \& Longobardi, C. (2013). The pupil-teacher relationship and gender differences in primary school. The Open Psychology Journal, 6, 69-75. https://doi.org/10.2174/1874350101306010069

Riegle-Crumb, C., Farkas, G., \& Muller, C. (2006). The role of gender and friendship in advanced course taking. Sociology of Education, 79(3), 206-228. https://doi.org/10.1177/003804070607900302

Robnett, R., \& Leaper, C. (2012). Friendship groups, personal motivation, and gender in relation to high school students' STEM career interest. Journal of Research on Adolescence, 23(4), 652-664. https://doi.org/10.1111/jora. 12013

Roeser, R. (2006). On the study of educational and occupational life-paths in psychology: Commentary on the special issue. Educational Research and Evaluation, 12(4), 409-421. https://doi.org/10.1080/13803610600765968

Ryan, R.M., \& Deci, E. L. (2000). Self-determination theory and the facilitation of intrinsic motivation, social development, and well-being. American Psychologist, 55(1), 68-78. https://doi.org/10.1037110003-066X.55.1.68

Roster, C. A., Lucianetti, L., \& Albaum, G. (2015). Exploring slider vs. categorical response formats in web-based surveys. Journal of Research Practice, 11(1), Article D1. Retrieved from http://jrp.icaap.org/index.php/jrp/article/view/509/413

Sax, L., Kanny, M., Riggers-Piehl, T., Whang, H., \& Paulson, L. (2015). “But I'm not good at math”: The changing salience of mathematical self-concept in shaping women's and men's STEM aspirations. Research in Higher Education, 56(8), 813-842. https://doi.org/10.1007/s11162-015-9375-x

School Curriculum and Standards Authority, Government of Western Australia. (2014). Western Australian 
curriculum and assessment online. Retrieved from http://www.scsa.wa.edu.au/

Seo, E., Shen, Y., \& Alfaro, E. C. (2019). Adolescents' beliefs about math ability and their relations to STEM career attainment: Joint consideration of race/ethnicity and gender. Journal of Youth and Adolescence, 48, 306-325. https://doi.org/10.1007/s10964-018-0911-9

Shumow, L., \& Schmidt, J. (2013). Academic grades and motivation in high school science classrooms among male and female students: Associations with teachers' characteristics, beliefs, and practices. Handbook of academic performance: Predictors, learning strategies and influences of gender (pp. 53-72).

Spearman, J., \& Watt, H. (2013). Women's aspirations towards "STEM" careers: A motivational analysis. In Conceptualising women's working lives: Moving the boundaries of discourse (pp. 175-192). Sense Publishers. https://doi.org/10.1007/978-94-6209-209-9

Spilt, J. L., Koomen, M. Y., \& Jak, S. (2012). Are boys better off with male and girls with female teachers? Journal of School Psychology, 50, 363-378. https://doi.org/10.1016/j.jsp.2011.12.002

Steffens, M., Jelenec, P. \& Noack, P. (2010). On the leaky math pipeline: Comparing implicit math-gender stereotypes and math withdrawal in female and male children and adolescents. Journal of Educational Psychology 102(4), 947-963. https://doi.org/10.1037/a0019920.

Tabachnick, B. G. \& Fidell, L.S. (2013). Using multivariate statistics. Pearson: Boston.

Tajfel, H. and Turner, J.C. (1986) The social identity theory of intergroup behavior. In S. Worche W.G. Austin, W.G. (Eds.), Psychology of intergroup relation, Hall Publishers, Chicago.

Timms, M., Moyle, K., Weldon, P. R., \& Mitchell, P. (2018). Challenges in STEM learning in Australian schools. Australian Council for Educational Research. Retrieved from https://research.acer.edu.au/policyinsights/7/

Trautwein, U., Marsh, H. W., Nagengast, B., Lüdtke, O., Nagy, G., \& Jonkmann, K. (2012). Probing for the multiplicative term in modern expectancy-value theory: A latent interaction modeling study. Journal of Educational Psychology, 104, 763-777. https://doi.org/10.1037/a0027470

UNESCO. (2017). Cracking the code: girls' and women's education in science, technology, engineering and mathematics (STEM). UNESCO. Retrieved from https://unesdoc.unesco.org/ark:/48223/pf0000253479

Wang, M., \& Degol, J. (2013). Motivational pathways to STEM career choices: Using expectancy-value perspective to understand individual and gender differences in STEM fields. Developmental Review, 33(4), 304-340. https://doi.org/10.1016/j.dr.2013.08.001

Wang, M., Ye, F., \& Degol, J. (2017). Who chooses STEM careers? Using a relative cognitive strength and interest model to predict careers in science, technology, engineering, and mathematics. Journal of Youth and Adolescence, 46(8), 1805-1820. https://doi.org/10.1007/s10964-016-0618-8

Wang, M., \& Eccles, J. (2012). Adolescent behavioral, emotional, and cognitive engagement trajectories in school and their differential relations to educational success. Journal of Research on Adolescence, 22(1), 31-39. https://doi.org/10.1111/j.1532-7795.2011.00753.x

Wang, M.-T., Eccles, J. S., \& Kenny, S. (2013). Not lack of ability but more choice: Individual and gender differences in choice of careers in science, technology, engineering, and mathematics. Psychological Science, 24(5), 770-775. https://doi.org/10.1177/0956797612458937

Wang, M., \& Kenny, S. (2014). Gender differences in personal aptitudes and motivational beliefs for achievement in and commitment to math and science fields. In Gender differences in aspirations and attainment: A life course perspective (pp. 266-284). Cambridge University Press. https://doi.org/10.1017/CBO9781139128933.017

Watt, H. M. G. (2004). Development of adolescents' self-perceptions, values, and task perceptions according to gender and domain in $7^{\text {th }}$ - through $11^{\text {th }}$-grade Australian students. Child Development $75(5), 1556-1574$. https://doi.org/10.1111/j.1467-8624.2004.00757

Watt, H. M. G. (2016). Promoting girls' and boy's engagement and participation in senior secondary STEM fields and occupational aspirations. Retrieved https://research.acer.edu.au/cgi/viewcontent.cgi?article=1285\&context=research_conference

Watt, H. M. G., Hyde, J. S., Petersen, J., Morris, Z. A., Rozek, C. S., \& Harackiewicz, J. M. (2017). Mathematics-A critical filter for stem-related career choices? A longitudinal examination among Australian and US adolescents. Sex Roles, 77, 254-271. https://doi.org/10.1007/s11199-016-0711-1 
Watt, H. M. G., Shapka, J. D., Morris, Z. A., Durik, A. M., Keating, D. P., \& Eccles, J. S. (2012). Gendered motivational processes affecting high school mathematics participation, educational aspirations, and career plans: A comparison of samples from Australia, Canada, and the United States. Developmental Psychology, 48 (6), 1594-1611. https://doi.org/10.1037/a0027838

Watt, H. M. G., \& Goos, M. (2017). Theoretical foundations of engagement in mathematics. Mathematics Education Research Journal, 29 (2), 133-142. https://doi.org/10.1007/s13394-017-0206-6

Wigfield, A., \& Eccles, J. S. (2000). Expectancy-value theory of achievement motivation. Educational Psychology, 25, 68-81. https://doi.org/10.1006/ceps.1999.1015

Wilson, R. \& Mack, J. (2014). Declines in high school mathematics and science participation: Evidence of students' and future teachers' disengagement with maths. International Journal of Innovation in Science and Mathematics Education, 22(7), 35-48.

\section{Copyrights}

Copyright for this article is retained by the author(s), with first publication rights granted to the journal.

This is an open-access article distributed under the terms and conditions of the Creative Commons Attribution license (http://creativecommons.org/licenses/by/4.0/). 